\title{
Ethanol-induced changes in the fatty acid composition of Lactobacillus hilgardii, its effects on plasma membrane fluidity and relationship with ethanol tolerance
}

\author{
J.A. Couto, N. Rozès' ${ }^{1}$ and T. Hogg \\ Escola Superior de Biotecnologia, Universidade Católica Portuguesa, Porto, and 'Instituto de Tecnologia Química \\ e Biológica, Oeiras, Portugal \\ 5565/11/95: received 23 November 1995, revised 23 January 1996 and accepted 29 January 1996
}

\begin{abstract}
J.A. COUTO, N. ROZES AND T. HOGG. 1996. The effect of environmental ethanol concentration on the fatty acid composition of strains of Lactobacillus hilgardii, differing in their tolerance to ethanol, was determined. A marked increase in the proportion of lactobacillic acid (a cyclopropane fatty acid) and a decrease in oleic and vaccenic acids with increasing ethanol concentration was observed. The amount of lactobacillic acid determined at standard conditions $\left(25^{\circ} \mathrm{C}, 0 \%\right.$ ethanol) was found to be proportional to the ethanol tolerance of the strains studied. The effect of this alcohol on plasma membrane fluidity was studied by differential scanning calorimetry. The adaptive response to growth in the presence of high concentrations of ethanol produced membranes which, within the limits of ethanol tolerance, maintained the fluidity and integrity in an environment which tends to increase membrane rigidity. When pre-adapted cells are analysed in the absence of environmental ethanol there is a measurable increase in fluidity. It is proposed that this phenomenon may be correlated with the increase in the proportion of lactobacillic acid. The existence of a relationship between membrane fluidity and ethanol tolerance is discussed.
\end{abstract}

\section{INTRODUCTION}

Most bacteria exhibit a dose-dependent inhibition of growth over the range $1 \%$ to $10 \%(\mathrm{v} / \mathrm{v})$ ethanol and few organisms grow at concentrations above $10 \%$ (Ingram and Buttke 1984). Organisms of the genus Lactobacillus can be considered exceptional in this respect in that many of these grow in higher concentrations of this alcohol. Certain strains of Lact. hilgardii, along with strains of certain other lactobacilli ( Lact. fructivorans and Lact. homohiochii) are some of the most ethanol-tolerant of all free-living vegetative cells (Uchida 1975; Kandler and Weiss 1986). Due to their high intrinsic resistance, isolates of Lact. hilgardii obtained from Douro fortified wine (Couto and Hogg 1994) present a useful model for the further study of mechanisms of resistance to this environmental challenge.

The primary site through which the cell maintains contact

Correspondence to: Dr T. Hogg, Escola Superior de Biotecnologia, Universidade Católica Portuguesa, R. Dr António Bernardino de Almeida, 4200 Porto, Portugal. with its direct environment is the plasma membrane. It is therefore likely that it would be the primary site for the expression of an adaptive response to environmental ethanol (Dombeck and Ingram 1984). The potency of alcohols in eliciting alterations at the plasma membrane level has been shown to be directly related to their hydrophobicity or octanol-water partition coefficients (Ingram 1986), supporting the suggestion of a hydrophobic site of action. That ethanol induces changes in the lipid membrane composition of several organisms, apparently to favour microbial growth and survival in its presence, has also been shown. Among eukaryotes, Saccharomyces cerevisiae is probably the most studied organism in this respect (Thomas et al. 1978; Mishra and Prasad 1989; Castillo Agudo 1992; Sajbidor and Grego 1992; Alexandre et al. 1993, 1994) but other yeasts, considered to have elevated resistance to ethanol, have also been studied: Schizosaccharomyces pombe (Koukou ct al. 1990), Kloekera apiculata (Alexandre et al. 1994) and Zygosaccharomyces bailii (Couto and Huis in't Veld 1995). These yeast cells were grown in the presence of increasing concentrations of ethanol and subsequently analysed for phospholipid fatty acyl com- 
position. Results show a dose-dependent increase in the content of unsaturated fatty acids. Sterol composition can also be affected by the presence of ethanol as reported by Alexandre et al. (1994), who found a significant increase in ergosterol in cells grown at near limiting ethanol concentrations in a tolerant strain of $S$. cerevisiae. Among bacteria, Escherichia coli has, as in most aspects, been extensively investigated in terms of ethanol tolerance mechanisms (Ingram 1976; Ingram and Vreeland 1980; Buttke and Ingram 1980); indeed changes in fatty acid composition have been shown to be analogous to what has been described above for yeasts. Other bacteria which have also been the subject of study include 'Lact. heterohiochii' (now included in Lact. fructivorans) (Uchida 1975), Bacillus subtilis (Rigomier et al. 1980), Clostridium thermocellum (Herrero et al. 1982) and Zymomonas mobilis (Bringer et al. 1985). It is worthy to note that not all studies within these organisms demonstrate the same trend in lipid changes.

The incorporation of more unsaturated fatty acids into membrane lipids would tend to cause an increase in fluidity (if measured in a constant environment). Such composition shift is seen as an adaptive response of the cell to ethanol, compensating for the direct physico-chemical interaction which this compound has with the membrane (Ingram 1976). This model, whilst being widely reported, is apparently not universally applicable to all organisms. Exceptions have been reported by Dombeck and Ingram (1984) who found that plasma membranes isolated from $E$. coli cells grown in the presence of ethanol were more rigid than those from control cells and Rigomier $e t$ al. (1980) who observed that in $B$. subtilis ethanol-induced changes in fatty acids decreased rather than increased membrane fluidity.

A wide variety of physical methods can be applied to investigate the organization and dynamics of the lipid bilayer in model and biological membranes. Differential scanning calorimetry (DSC), the method chosen for this work, is a thermoanalytical technique that monitors changes in physical or chemical properties of materials as a function of temperature by detecting the heat changes associated with such processes (Biliaredis 1983). It has proved to be of great value in studies of the thermotropic behaviour of lipids in biological membranes (McElhaney 1982) and has been applied to the study of adaptive mechanisms of membranes in some bacterial species (Reizer et al. 1985; Lepock et al. 1990). In this work, ethanol-induced alterations in the fatty acid composition of Lact. hilgardii are analysed and its relationship with plasma membrane fluidity and ethanol tolerance is discussed.

\section{MATERIALS AND METHODS}

\section{Bacterial strains and cultural conditions}

The present studies were performed with the following strains: Lact. hilgardii 5 and Lact. hilgardii 28 isolated from
Douro Valley fortified wine and identified as described by Couto and Hogg (1994); and Lact. hilgardii NCFB 264 (type strain) obtained from the National Collection of Food Bacteria (NCFB), AFRC Institute of Food Research, Reading Laboratory, Shinfield, UK. Cells were grown at $25^{\circ} \mathrm{C}$ in MRS broth (Lab M) with $\mathrm{pH}$ adjusted to 4.5 at different concentrations of ethanol: $0,5,10,15$ and $18 \%(v / v)$ for Lact. hilgardii 5; 0, 5, 10 and $15 \%$ for Lact. hilgardii 28 ; and $0,5,10$ and $14 \%$ for Lact. hilgardii NCFB 264.

\section{Bacterial fatty acid analysis}

Cells $(1 \mathrm{ml})$ from stationary phase cultures were harvested by centrifugation $(8000 \mathrm{~g}, 10 \mathrm{~min})$ and washed twice with sterile water. The analysis of the fatty acid composition of cells was carried out as described by Rozès et al. (1993).

\section{Isolation of membrane vesicles}

Membrane vesicles were obtained following the procedure described by Otto et al. (1982). To achieve proper lysis of cells the amount of lysozyme was increased from 5 to $20 \mathrm{mg}$ $\mathrm{ml}^{-1}$.

\section{Differential scanning calorimetry}

Cultures were centrifuged at $8000 \mathrm{~g}$ for $10 \mathrm{~min}$, washed twice in $0.1 \mathrm{~mol} \mathrm{l}^{-1}$ potassium phosphate buffer $(\mathrm{pH} 7)$ at $4^{\circ} \mathrm{C}$ containing $100 \mu \mathrm{mol}^{-1}$ chloramphenicol (Sigma) (to prevent protein synthesis during harvest and manipulation) and resuspended in the same solution. Intact cells or membrane vesicles were weighed (15-20 $\mathrm{mg}$ wet $\mathrm{wt}$ ) and hermetically sealed in aluminium DSC pans.

DSC scans were obtained with a Shimadzu DSC-50 calorimeter. Samples were heated at $5^{\circ} \mathrm{C} \min ^{-1}$ from about -6 to $80^{\circ} \mathrm{C}$, using as reference, a pan containing the phosphate buffer or cells grown in the absence of ethanol (L0). After heating, some of the samples studied were cooled (using liquid nitrogen) and re-scanned to investigate the reversibility of the thermograms. Temperature and heat were calibrated according to the manufacturer's instructions using the melting of indium as standard.

\section{RESULTS}

Previous studies in this laboratory have shown that the strains used in this work have different tolerances to ethanol; Lact. hilgardii 5, 28 and NCFB 264 not being able to grow at concentrations higher than 18,16 and $14 \%$, respectively (data not shown). 


\section{Fatty acid composition of Lact. hilgardii and ethanol- induced changes}

From Table 1, an initial observation is that saturated, monounsaturated and cyclic fatty acids were encountered in the three strains analysed. Jactobacillic acid (C19) is present at high levels in all strains. Palmitic acid (C16:0) is the predominant fatty acid in strain 5 and is also present at a high level in strain 28. Oleic acid (C18:1 cis9) predominates in Lact. hilgardii NCFB 264, being identified at a high level also in strain 28. Vaccenic acid (C18:1 cis11) appeared at a similar concentration as oleic acid in strain 28 and at lower levels in strains 5 and NCFB 264. Lactobacillus hilgardii NCFB 264 and 28 contain a small amount of eicosenoic acid (C20:1) which was not found in strain 5 .

The distribution of the fatty acyl residues was examined in early stationary phase cultures grown at different concentrations of ethanol and is shown in Fig. 1. The presence of this alcohol in the growth medium results in considerable changes in the fatty acid composition of the bacteria studied. for all strains examined, the percentage of C19 increased with increasing ethanol concentration (except at 14 and $15 \%$ $v / v$ in strains NCFB 264 and 28, respectively). The proportion of C16:0 decreased in strains 5 and 28 with increasing ethanol concentrations whereas it has increased in strain NCFB 264. The percentage of both C18:1 cis9 and C18:1 cisll decreased in all strains; particularly noted is the depletion of C18:1 cis 9 in strains 28 and NCFB 264 as one of the major fatty acids in these organisms. The fatty acid C.20:1 decreased and was not detected in cells grown at the higher concentrations of ethanol. The amounts of the other fatty acids did not considerably change with the presence of ethanol.

\section{The influence of ethanol on membrane fluidity in Lact. hilgardii 5}

When whole cells or isolated membranes of Lact. hilgardii 5 grown in the absence of ethanol were analysed by DSC with potassium phosphate buffer as reference, two endothermic transitions were observed on the first heating scan (Fig. 2). After cooling the samples, rescanning at the same heating rate yielded DSC curves presenting only one of these two transitions. As similar results were obtained for whole cells and isolated membranes, subsequent experiments were performed using whole cells.

To avoid the formation of the initial transient deflection, noted in curves of Fig. 2 between 0 and $10^{\circ} \mathrm{C}$, apparently due to different heating capacities between sample and reference, cells grown in the absence of ethanol (L0) were used as reference in place of buffer. This procedure allows the direct comparison, in the same thermogram, of the position of the gel to liquid-crystalline phase transition of the lipids from cells grown without and in the presence of different concentrations of ethanol. In this way, endothermic events occurring in the reference are indicated by peaks while endothermic events in the sample are represented as troughs.

No peaks or troughs were noted when $\mathrm{L} 0$ cells were run in both reference and sample positions (Fig. 3A). The rescan using cells grown at $10 \%$ ethanol ( 110$)$ as sample formed a definite peak (melting temperature $\left[T_{m}\right], 26 \cdot 7^{\circ} \mathrm{C}$ ) (Fig. 3B). The formation of a single peak indicates that the lipid transition in both LO and L10 cells occurs at about the same temperature, the appearance of the peak being probably due to a higher heat absorption by the L0 cells caused by slight variations in sample mass or by the intrinsic enthalpy of the transition. In Fig. $3 \mathrm{C}$ the trough $\left(T_{m} 22 \cdot 2^{\circ} \mathrm{C}\right)$ represents the lipid phase transition of cells grown at $15 \%$ ethanol (L15) and the peak $\left(T_{m} 27.5^{\circ} \mathrm{C}\right)$ represents the same event in $\mathrm{LO}$ cells. Figure 3D also shows two thermal events, the first $\left(T_{m}\right.$ $19.8^{\circ} \mathrm{C}$ ) being due to cells grown at $18 \%$ ethanol $(\mathrm{L} 18)$ in the sample position. The results from Figs $3 \mathrm{C}$ and $3 \mathrm{D}$ suggest that L15 and L18 cells have their lipid phase transitions shifted to lower temperatures. Data concerning these shifts are summarized in Table 2, the overall trend being a progressive lowering of the temperature of transition with increasing concentrations of ethanol in growth medium. This

Table 1 Fatty acid composition (percentage of total) of three strains of Lactohacillus hilgardii grown at standard conditions $\left(25^{\circ} \mathrm{C}, 0 \%\right.$ ethanol)

\begin{tabular}{|c|c|c|c|c|c|c|c|c|c|}
\hline \multirow{2}{*}{$\begin{array}{l}\text { Lactobacillus } \\
\text { strain }\end{array}$} & \multicolumn{9}{|c|}{ Fatty acid as $\%$ of total } \\
\hline & $14: 0$ & $16: 0$ & $16: 1$ & $17 \Delta$ & $18: 0$ & $18: 1 \mathrm{cis} 9$ & $18: 1 \operatorname{cis} 11$ & $19 \Delta$ & $20: 1$ \\
\hline hilgardii 5 & $3 \cdot 60 \pm 0 \cdot 89^{*}$ & $39 \cdot 40 \pm 2 \cdot 82$ & $2.65 \pm 0.87$ & $0 \cdot 51 \pm 0 \cdot 01$ & $1 \cdot 39 \pm 0 \cdot 60$ & $6 \cdot 37 \pm 1 \cdot 06$ & $9 \cdot 05 \pm 0.72$ & $37 \cdot 04 \pm 1 \cdot 89$ & ND \\
\hline hilgardii 28 & $4 \cdot 50 \pm 0 \cdot 16$ & $25.76 \pm 0.35$ & $6.98 \pm 0 \cdot 16$ & $0.31 \pm 0.02$ & $0.48 \pm 0.01$ & $15 \cdot 05 \pm 0 \cdot 15$ & $15 \cdot 27 \pm 0 \cdot 18$ & $31 \cdot 06 \pm 0 \cdot 36$ & $0.59 \pm 0.03$ \\
\hline $\begin{array}{l}\text { hilgardii } \\
\quad \text { NCFB } 264\end{array}$ & $10.95 \pm 0 \cdot 14$ & $9 \cdot 48 \pm 0 \cdot 08$ & $9 \cdot 40 \pm 0 \cdot 07$ & ND & $0.93 \pm 0.06$ & $32 \cdot 15 \pm 0 \cdot 12$ & $7 \cdot 76 \pm 0 \cdot 05$ & $26 \cdot 45 \pm 0 \cdot 25$ & $2 \cdot 87 \pm 0 \cdot 03$ \\
\hline
\end{tabular}

* Mean \pm S.D. of three measurements.

NI), Not detected. 

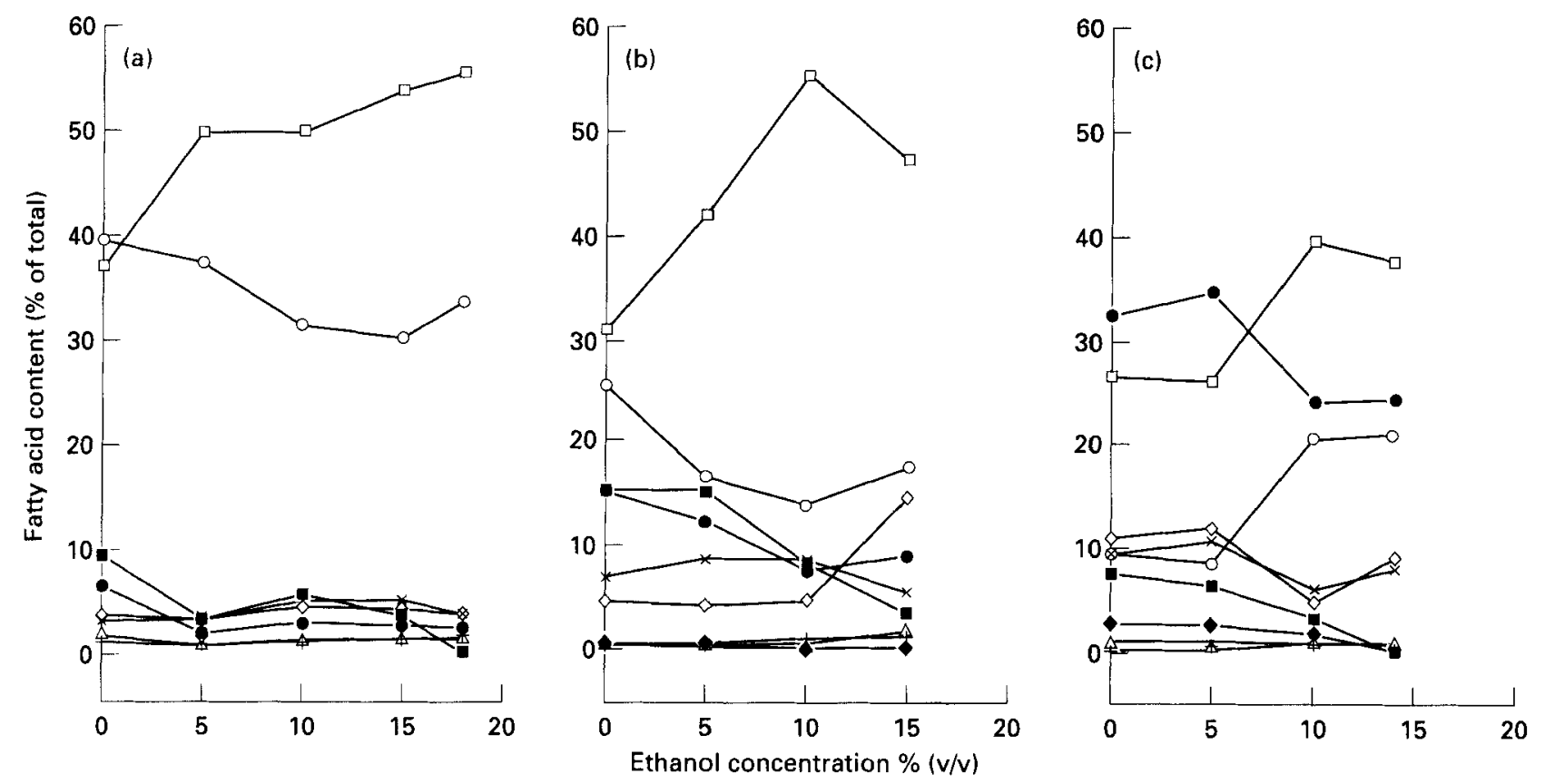

Fig. 1 Fatty acid alterations in (a) Lactobacillus hilgardii 5, (b) Lact. hilgardii 28 and (c) Lact. hilgardii NCFB 264 grown at various concentrations of ethanol. $\diamond$, Myristic acid; $\bigcirc$, palmitic acid; $x$, palmitoleic acid; + , methylenehexadecanoic acid; $\triangle$, stearic acid; $\mathbf{D}$, vaccenic acid;, oleic acid; $\square$, lactobacillic acid; $\boldsymbol{\Delta}$, eicosenoic acid

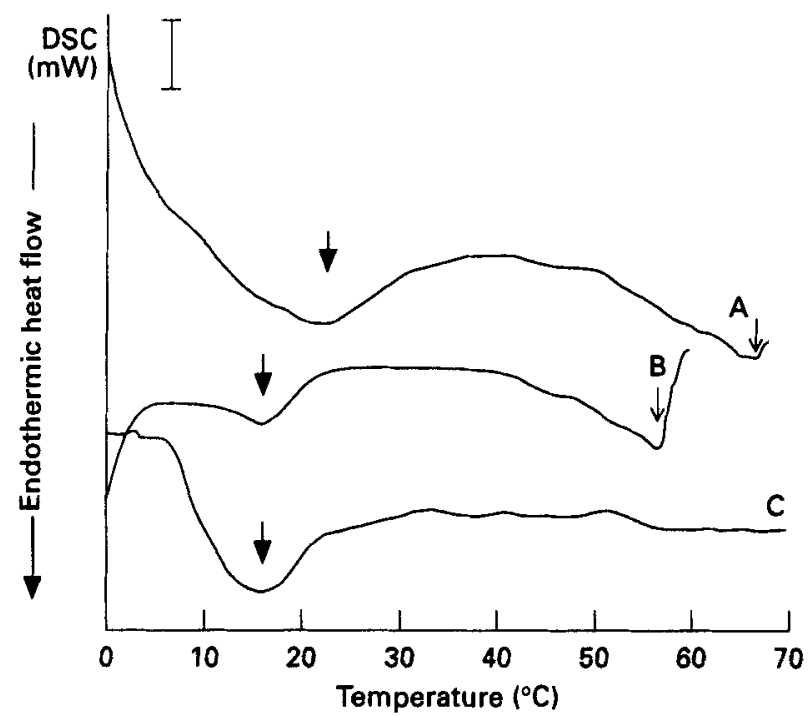

Fig. 2 Thermograms obtained by differential scanning calorimetry (DSC) of Lactobacillus hilgardii 5 grown at $0 \%$ ethanol. $A$, Whole cells; $B$, isolated membranes before protein denaturation (first scan); $C$, isolated membranes after protein denaturation (rescan). In all thermograms $0.1 \mathrm{~mol} \mathrm{I}^{-1}$ potassium phosphate buffer $(\mathrm{pH} 7)$ was used as reference. $(\downarrow)$ indicates position of lipid transition, $(\downarrow)$ indicates position of protein denaturation. Bar, $0.2 \mathrm{~mW}$

indicates that at high concentrations of ethanol (15-18\%), cells of Lact hilgardii 5 produce cytoplasmic membranes with

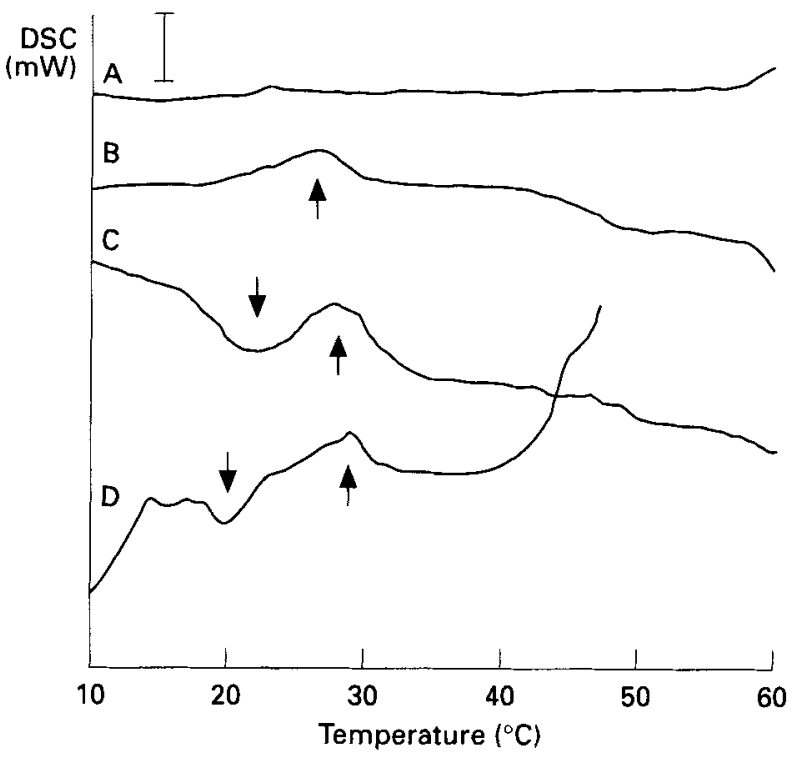

Fig. 3 Thermograms obtained by differential scanning calorimetry (DSC) of whole cells of Lactobacillus hilgardii 5 grown at (A) $0 \%$, (B) $10 \%$, (C) $15 \%$ and (D) $18 \%$ ethanol. All thermograms were obtained using cells grown at $0 \%$ ethanol as reference. $(\uparrow)$ indicates position of peaks, $(\downarrow)$ indicates position of troughs. Bar, $0.2 \mathrm{~mW}$

an increased proportion of low melting lipids. From Fig. 4 it is noted that this is not the case for Lact hilgardii NCFB 264 grown at limiting concentrations of ethanol (14\%). 
Table 2 Transition temperatures of whole cells of Lactobacillus hilgardii 5 grown at different concentrations of ethanol

\begin{tabular}{llll}
\hline \multirow{3}{*}{$\begin{array}{l}\text { Ethanol concentration } \\
\text { \% } \% / \mathrm{v})\end{array}$} & $T_{\mathrm{0}}$ & $T_{\mathrm{m}}$ & $T_{\mathrm{c}}$ \\
\cline { 2 - 4 } & & & \\
\hline 0 & $21 \cdot 0 \pm 0 \cdot 6^{*}$ & $27 \cdot 4 \pm 0 \cdot 8$ & $33 \cdot 8 \pm 0 \cdot 9$ \\
15 & $18 \cdot 4 \pm 0 \cdot 5$ & $22 \cdot 3 \pm 0 \cdot 7$ & $26 \cdot 1 \pm 0 \cdot 6$ \\
18 & $17 \cdot 2 \pm 1 \cdot 2$ & $20 \cdot 7 \pm 0 \cdot 9$ & $24 \cdot 5 \pm 1 \cdot 5$ \\
\hline
\end{tabular}

$T_{i /}$, Onset of transition; $T_{\mathrm{m}}$, melting temperature; $T_{\mathrm{e}}$, end of transition.

${ }^{*}$ Mean $\pm S . D$. of three measurements.

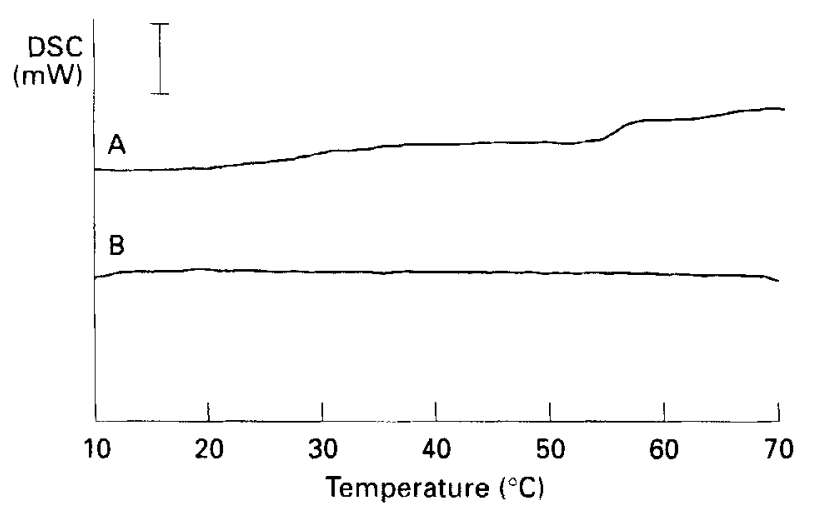

Fig. 4 Thermograms obtained by differential scanning calorimetry (DSC) of whole cells of Lactobacillus hilgardii NCFB 264 grown at (A) $0 \%$ and (B) $14 \%$ ethanol. Thermograms were obtained using cells grown at $0 \%$ ethanol as reference. Bar, $0 \cdot 2 \mathrm{~mW}$

\section{DISCUSSION}

Microbial resistance to ethanol has often been related to the fatty acid composition of plasma membrane lipids (Ingram and Buttke 1984). A review of the literature indicates that it is difficult to find a specific pattern of fatty acids common to organisms showing high ethanol tolerance. From the results of this study it is noted that Lact. hilgardii does not show a similar fatty acid composition to other ethanol-tolerant lactobacilli. This species does not contain the very long chain fatty acids (C20-C30) (only very small amounts of $\mathrm{C} 20: 1$ were found for two strains) reported to exist in 'Lact. heterohiochi' (current name Lact. fructivorans), a spoilage bacterium of Japanese rice wine (Saké) that can grow in media containing more than $20 \%(\mathrm{v} / \mathrm{v})$ ethanol (Uchida 1974). This organism was found to produce unusually long chain fatty acids and this inherent and unique character was considered responsible for, or at least related to, the high resistance of this species to ethanol. According to this author, it is likely that the presence of long hydrocarbon chains in membrane lipid com- ponents provides a more fortified hydrophobic barrier regarded as beneficial for survival in the presence of ethanol. The mechanism for this has been suggested as an increase in the surface area for hydrophobic and van der Waals interactions and a decrease of the polarity within the hydrophobic core (Carey and Ingram 1983).

Lactobacillus hilgardii 5 and 28 do not contain large proportions of the unsaturated fatty acids C18:1 cis11 or C18:1 cis9. It was observed for the three strains studied that the amounts of these compounds decreased with increasing ethanol concentrations. This is not in accordance with the evidence found in the literature which largely stresses the importance of membrane lipid unsaturated fatty acids in ethanol tolerance. Comparing the fatty acid composition of ethanol-tolerant organisms it is possible to note that C18:1 is present as a major fatty acyl residuc as reported in $Z$. mobilis (Carey and Ingram 1983; Bringer et al. 1985), Cl. thermocellum (Herrero et al. 1992), S. cerevisiae (Giudici and Guerzoni 1983) and Schiz. pombe (Koukou et al. 1990). In the case of Z. mobilis, C18:1 cis11 represents over $60 \%$ of the total acyl chains in the membrane lipids (Bringer et al. 1985). This acid is also the most abundant fatty acid in E. coli (Ingram 1976) with increasing proportions in cells grown in the presence of ethanol. Carey and Ingram (1983) considered that the fatty acid composition of $Z$. mobilis, an obligately ethanol-producing organism, represents an extreme of the trend observed in $E$. coli and so it may represent an evolutionary adaptation for survival in the presence of ethanol.

Referring solely to compositional alterations in the fatty acid complement of the plasma membrane, a final observation is that the cyclopropane lactobacillic acid (C19) is the compound which alters most with varying ethanol concentrations in the Lact. hilgardii strains analysed (Fig. 1). Potential mechanistic considerations of this observation are dealt with below.

Concerning the DSC data of whole cells and isolated membranes of cells grown in the absence of ethanol, two endothermic transitions were detected, the rescanning producing only the lower temperature transition (Fig. 2). The first region of heat absorption, which appeared in both scan and rescan, is consistent with a reversible transition in the lipid component of the membrane, the second region being probably due to an irreversible denaturation of the protein component (Melchior et al. 1970; Ashe and Steim 1971; McElhaney 1989). The lipid and protein transitions of whole cells occur at slightly higher temperatures than in the isolated membranes, an observation noted also by Ashe and Steim (1971) with Micrococcus lysodeikticus. These authors suggested that the interaction between the membrane and the cell wall might be responsible for the higher transitions in whole cells.

In this study, cells grown at $15 \%$ and $18 \%(\mathrm{v} / \mathrm{v})$ ethanol (L15 and L18 cells) show lipid phase transition at lower temperatures than cells grown in the absence of ethanol, these results suggesting that the adaptation of cells after exposure to 
ethanol produces a more 'fluid' membrane. The fluidization response can be interpreted as a counteraction to the physicochemical effect of ethanol on membranes. Based on the hypothesis of 'homeoviscous adaptation' (Sinensky 1974) the production of a more fluid membrane is a compensation for the increase in 'rigidity' due to ethanol presence. This behaviour is consistent with ethanol-induced changes occurring in Clostridium (Herrero et al. 1982; Curatolo et al. 1983; Baskaran et al. 1995) and in S. cerevisiae (Mishra and Prasad 1989; Lloyd et al. 1993; Alexandre et al. 1994) but contrary to findings with $B$. subtilis (Rigomier et al. 1980) where changes in fatty acids decreased membrane fluidity.

Since C19 has physical properties similar to unsaturated fatty acids (Law et al. 1962; McElhaney 1989), the increase in the fluidity of the membrane seems to be associated with the increase in the proportion of this lipid in the membrane. The role of cyclopropane fatty acids in the prevention of close packing of lipids in cell membranes, which makes them more elastic and flexible during exposure to environmental conditions, has been proposed by Kodicek (1963). Smittle $e t$ al. (1974) have also reported the C19 fatty acid to be one of the most closely related to the resistance of Lact. bulgaricus to freezing. Hence, the adaptation mechanism to ethanol could be related to the capacity of the cell to raise the proportion of C19.

L10 cells did not show a detectably different thermogram if compared with L0 cells. The alteration in the fatty acid composition induced by the presence of $10 \%$ ethanol (Fig. 1a) may not alter the membrane fluidity to a measurable level. Certainly it has been observed that $10 \%$ ethanol is not inhibitory to Lact. hilgardii 5 , indeed growth of this strain is actually stimulated by concentrations up to $10 \%$ (data not shown).

As noted, cells of strain NCFB 264, even when grown at $14 \%$ ethanol, did not show apparent alteration in membrane fluidity (Fig. 4B). This is possibly due to the concomitant relative increase of $\mathrm{C} 16: 0$ and $\mathrm{C} 19$. As a saturated fatty acid, C16:0 would tend to oppose the fluidizing effect of $\mathrm{C} 19$. The ability of strain 5 to alter its membrane lipid composition, and thus fluidity, to a greater extent is reflected in its ability to tolerate higher concentrations of ethanol. It is, according to the literature reviewed by Ingram and Buttke (1984), consistent that these two characters are related.

Ethanol tolerance among strains of Lact. hilgardii apparently has some taxonomic relevance. The hierarchical level at which it is of importance is an area of current study. It can be observed in Table 1 that the amount of C19 present in the three strains studied in this work, grown under control conditions (absence of ethanol) is proportional to their ethanol resistance. The evidence presented in this study suggests that there exists a relationship between membrane fatty acid composition and ethanol tolerance in Lact. hilgardii in which the important role of $\mathrm{C} 19$ in the response of cells to the presence of ethanol should be stressed.

\section{ACKNOWLEDGEMENTS}

JAC was supported by a JNICT (Junta Nacional de Investigação Científica e Tecnológica, Portugal) postgraduate studentship. This work was made possible by the generous support of EC-AIR-CT94 2468 project on the deterioration of fortified wine.

\section{REFERENCES}

Alexandre, H., Rousseaux, I. and Charpentier, C. (1993) Ethanol adaptation mechanisms in Saccharomyces cerevisiae. Biotechnology and Applied Biochemistry 20, 173-183.

Alexandre, H., Rousseaux, I. and Charpentier, C. (1994) Relationship between ethanol tolerance, lipid composition and plasma membrane fluidity in Saccharomyces cerevisiae and Kloeckera apiculata. FEMS Microbiology Letters 124, 17-22.

Ashe, G.B. and Steim, J.M. (1971) Membrane transitions in Grampositive bacteria. Biochimica et Biophysica Acta 233, 810-814.

Baskaran, S., Ahn, H.J. and Lynd, L.R. (1995) Investigation of the ethanol tolerance of Clostridium thermosaccharolyticum in continuous culture. Biotechnology Progress 11, 276-281.

Biliaredis, C. (1983) Differential scanning calorimetry in food research - a review. Food Chemistry 10, 239-265.

Bringer, S., Hartner, T., Poralla, K. and Sahm, H. (1985) Influence of ethanol on the hopanoid content and the fatty acid pattern in batch and continuous cultures of Zymomonas mobilis. Archives of Microbiology 140, 312-316.

Buttke, T.M. and Ingram, L.O. (1980) Ethanol-induced changes in lipid composition of Escherichia coli: inhibition of saturated fatty acid synthesis in vitro. Archives of Biochemistry and Biophysics 203, $565-571$.

Carey, V.C. and Ingram, L.O. (1983) Lipid composition of $Z y m$ omonas mobilis: effects of ethanol and giucose. Fournal of Bacteriology 154, 1291-1300.

Castillo Agudo, L. (1992) Lipid content of Saccharomyces cerevisiae strains with different degrees of ethanol tolerance. Applied Microbiology and Biotechnology 37, 647-651.

Couto, J.A. and Hogg, T. (1994) Diversity of ethanol-tolerant lactobacilli isolated from Douro fortified wine: clustering and identification by numerical analysis of electrophoretic protein profiles. Fournal of Applied Bacteriology 76, 487-491.

Couto, M.M. and Huis in't Veld, J.H. (1995) Influence of ethanol and temperature on the cellular fatty acid composition of $Z y g o-$ saccharomyces bailii spoilage yeasts. Fournal of Applied Bacteriology 78, 327-334.

Curatolo, W., Kanodia, S. and Roberts, M.F. (1983) The effect of ethanol on the phase behavior of membrane lipids extracted from Clostridium thermocellum strains. Biochimica et Biophysica Acta 734, 336-341.

Dombeck, K.M. and Ingram, L.O. (1984) Effects of ethanol on the Escherichia coli plasma membrane. Journal of Bacteriology 157, 233-239.

Giudici, P. and Guerzoni, M.E. (1983) Relationship of cellular fatty acid composition to the ethanol productivity in Saccharomyces cerevisiae. Vini D'Italia 145, 147-152.

Herrero, A.A., Gomez, R.F. and Roberts, M.F. (1982) Ethanol- 
induced changes in the membrane lipid composition of $\mathrm{Clo}$ stridium thermocellum. Biochimica et Biophysica Acta 693, 195-204.

Ingram, L.O. (1976) Adaptation of membrane lipids to alcohols. faurnal of Bacteriology 125, 670-678.

Ingram, I..O. (1986) Microbial tolerance to alcohol: role of the cell membranc. Trends in Biotechnology 4, 40-44.

Ingram, L.O. and Buttke, T. (1984) Effects of alcohols on microorganisms. Advances in Microbial Physiology 25, 253-300.

Ingram, L.O. and V reeland, N.S. (1980) Differential effects of ethanol and hexanol on the Escherichia coli cell envelope. fournal of Bacteriology 144, 481-488.

Kandler, O. and Weiss, N. (1986) Regular, nonsporing gram-positive rods. In Bergey's Manual of Systematic Bacteriology, Section 14. pp. $1208-1234$.

Kodicek, E. (1963) Aspects of the constitution of bacterial membranes. In Recent Progress in Microbiology, Vol. 8, ed. Gibbons, N.E. pp. 23-37. Toronto, Ontario, Canada: University of Toronto Press.

Koukou, A.I., Tsoukatos, D. and Drainas, C. (1990) Effect of ethanol on the phospholipid and fatty acid content of Schizosaccharomyces pombe membranes. Journal of General Microbiology 136, 1271-1277.

Law, J.H., Zalkin, H. and Kaneshiro, T. (1962) Transmethylation reactions in bacterial lipids. Biochimica et Biophysica Acta 70, 143151.

Lepock, J.R., Frey, H.E. and Inniss, W.E. (1990) Thermal analysis by differential scanning calorimetry: relationship of protein denaturation in situ to maximum growth temperature. Biochimica et Biophysica Acta 105, 19-26.

Lloyd, D., Morrel, S., Carlsen, H.N., Degn, H., James, P.E. and Rowlands, C.R. (1992) Effects of growth with ethanol on fermentation and membrane fluidity of Sacharomyces cerevisiae. Yeast 9, 825-833.

McElhaney, R.N. (1982) The use differential scanning calorimetry and differential thermal analysis in studies of model and biological membranes. Chemistry and Physics of Lipids 30, 229-259.

McElhancy, R.N. (1989) The influence of membrane lipid composition and physical properties of membrane structure and function in Achnleplasma laidlamii. Critical Reviems in Microbislogy 17, $1-32$.
Melchior, D.L., Morowitz, H.J., Sturtevant, J.M. and Tsong, T.Y. (1970) Characterization of the plasma membrane of Mycoplasma laidlamii. Biochimica el Biophysica Acta 219, 114-122.

Mishra, P. and Prasad, R. (1989) Relationship between ethanol tolerance and fatty acid composition of Saccharomyces cerevisiae. Applied Microbiology and Biotechnology 30, 294298.

Otto, R., Lageveen, R.G., Veldkamp, H. and Konings, W.N. (1982) Lactate efflux-induced electrical potential in membrane vesicles of Streptococcus cremoris. Journal of Bacteriology 149, 733-738.

Reizer, J., Grossowicz, N. and Barenholz, Y. (1985) The effect of growth temperature on the thermotropic behavior of the membranes of a thermophilic Bacillus. Composition-structure-function relationships. Biochimica et Biophysica Acta 815, 268-280.

Rigomier, D., Bohin, J.P. and Lubochinsky, B. (1980) Effects of ethanol and methanol on lipid metabolism in Bacillus subtilis. Journal of General Microbiology 121, 139-149.

Rozès, N., Garbay, S., Denayrolles, M. and Lonvaud-Funel, A. (1993) A rapid method for the determination of bacterial fatty acid composition. Letters in Applied Microbiology 17, 126-131.

Sajbidor, J. and Grego, J. (1992) Fatty acid alterations in Saccharomyces cerevisiae exposed to ethanol stress. FEMS Microbiology Letters 93, 13-16.

Sinensky, M. (1974) Homeoviscous adaptation - a homeostatic process that regulates the viscosity of membrane lipids in Escherichia coli. Proceedings of the National Academy of Sciences USA 71, 522 525.

Smittle, R.B., Gilliland, S.E., Speck, M.L. and Walter, W.M. (1974) Relationship of cellular fatty acid composition to survival of Lactobacillus bulgaricus in liquid nitrogen. Applied Microbiology 27, 738-743,

Thomas, D.S., Hossack, J.A. and Rose, A.H. (1978) Plasma-membrane lipid composition and ethanol tolerance in Saccharomyces cerevisiae. Archives of Microbiology 117, 239-245.

Uchida, K. (1974) Lipids of alcoholophilic lactobacilli. II Occurrence of polar lipids with unusually long acyl chains in Lactobacillus heterohiochii. Biochimica et Biophysica Acta 369, 146-155.

Uchida, K. (1975) Effects of cultural conditions on the cellular fatty acid composition of Lactobacillus heterohiochii, an alcoholophilic bacterium. Agricultural Biology and Chemistry 39, 837-842. 